\title{
Palmemptyfruitbunch gasificationsimulationin circulating fluidized bed gasifier
}

\author{
Rudy Heryadi ${ }^{1 *}$, Aep Saepul Uyun ${ }^{1}$,Erkata Yandri $^{1,2}$, Syukri M Nur ${ }^{1,2}$, and Kamaruddin Abdullah ${ }^{1,2}$ \\ ${ }^{1}$ Graduate School of Renewable Energy, Darma Persada University, Jl. Radin Inten 2, P.Kelapa, East Jakarta, Indonesia 13450 \\ ${ }^{2}$ Center of Renewable Energy Studies, Darma Persada University, J1. Radin Inten 2, P.Kelapa, East Jakarta, Indonesia 13450
}

\begin{abstract}
Biomass from EFB is considered as potential renewable energy sources to be developed in Indonesia. EFB can be efficiently converted into valuable and useful gaseous products through gasification. Research about EFB gasification in various gasifier has been done, though little research about EFB simulation on CFB bed gasifier. The aim of this research is to simulate gasification of EFB on $\mathrm{CFB}$ gasifier by assuming that the gasification reaction isunder equilibrium condition. Method encompasses biomass feedstock, simulation basis manager, process description, simulation description, model validation, and sensitivity analysis. The model predicts $\mathrm{H}_{2}$ and $\mathrm{CO}$ fraction on syngas product in agreement with published real CFB gasification operation. The result shows that CFB gasifier performance is improving at high temperature above $800{ }^{\circ} \mathrm{C}$., and syngas conversion is higher under high temperature. The highest $\mathrm{H}_{2}$ yield achieved at $800^{\circ} \mathrm{C}$.Impact of $\mathrm{S} / \mathrm{B}$ has been investigated, and it is found that when value of $\mathrm{S} / \mathrm{B}$ is increasing, the more $\mathrm{H}_{2}$ produced. The value of ER below 1 is desired since the focus is to get $\mathrm{CO}$ together with $\mathrm{H}_{2}$. The lower ER value the higher syngas yield obtained. The model will be used as a basis for further chemical production simulation from EFB gasification.
\end{abstract}

\section{Introduction}

The need for renewable energy in Indonesia is a necessity. From various renewable energy alternatives available, renewable energy from biomass has great potential to be developed in Indonesia. The biomass potential in Indonesia is about $32 \mathrm{GWe}$, andrecent utilizationwas onlyaround $1,740.40 \mathrm{GWe}$ or $5.4 \%$ of the total potential [1]. It was estimated by [2] that biomass potential in Indonesia at 146.7 million tons per year equivalent to $470 \mathrm{GJ} / \mathrm{y}$.

Utilization of biomass to be used as one of energy source can be done through gasification process. Gasification is a thermochemical process that converts biomass into a gas called a producer gas or synthetic gas (syngas). Syngas is a fuel-based mixture consisting mainly of Hydrogen $\left(\mathrm{H}_{2}\right)$, Carbon Monoxide (CO), and Methane $\left(\mathrm{CH}_{4}\right)$ [3]. Syngas is a raw material for most other chemical products, such as Methanol, Ammonia, and Dimethyl Ether (DME). One of the biomasses that has big potential to be utilized is palm empty fruit bunch (EFB) waste. Total EFB waste generated is around 32 million tons per year[4].

Research related to the utilization of EFB as a renewable energy source of biomass has been done. Some of these are studies related to the manufacture of biomass pellets to be utilized as feeds of gasification and boiler reactors [5][6], research related to the utilization of EFB into bio-oil products [7] which discusses the conversion of EFB to bio-oil through pyrolysis pathway, research of EFB conversion into bio-syngas through experiment by using fluidized bed reactors performed by [8], and pyrolysis catalytic cracking method to produce bio-syngas with gasification was performed by [9] . Anotherresearch pertinent to the utilization of EFB through gasification pathwaywasstudy of [10]which discussed the gasification results of EFB by using entrained flow gasifier pilot scale, and gasifying agent used was steam and Oxygen $\left(\mathrm{O}_{2}\right)$.

Simulation of gasification process by using EFB to produce syngas and its derivative products by using Aspen Hysys process simulator had beendone by [11] which discussed about parametric analysis of bio-DME production. Another research about simulation of gasification process using Aspen Hysyswas conducted by [12],where the simulation done using Aspen Hysys on fixed bed downdraft gasifier, feedstock utilized was date palm waste.Reference[12] was discussing model developed based on real experiment on the downdraft gasifier, and the result discussed itself was a comparison of the actual syngas yield versus syngas yield from model developed with a variation on gasifier temperature and steam to biomass ratio only.

* Corresponding author: rudy.heryadi@live.com 
Unfortunately, not many simulations of EFB gasification research carried out by using Aspen Hysys, especially the one that simulate gasification on circulating fluidized bed (CFB) gasifier. Mostly, modelling of CFB gasifier based on biomass gasification were conducted by using Aspen Plus process simulator[13]-[17]. Based on thestudies carried out earlier, this research aimed to simulate and develop model of EFB gasification in CFB gasifierby utilizing Aspen Hysys process simulator.This model is developed to investigate key operating parameters.

\section{Theory of Gasification and Simulation}

\subsection{Gasification}

Gasification is a process that converts biomass into a gaseous fuel called producer gas $\left(\mathrm{CO}, \mathrm{H}_{2}, \mathrm{CH}_{4}\right.$, etc.) using a little air or oxygen/steam. Reactionoccurs is incomplete combustion. According to the reference[9], gasification reactions involve several series of chemical reactions such as: drying, pyrolysis, combustion processes, gasification processes, and auxiliary processes such as gas and water phase displacement reactions. Basically, limited amount of oxygen/steam or air is introduced into the gasification reactor to allow biomass to burn to produce carbon dioxide $\left(\mathrm{CO}_{2}\right)$ and energy, which in turn will trigger the conversion of biomass into hydrogen $\left(\mathrm{H}_{2}\right)$ and additional $\mathrm{CO}_{2}$. Further reactions occur when $\mathrm{CO}$ is formed and residual water from biomass produces excess $\mathrm{CH}_{4}$ and $\mathrm{CO}_{2}$. The reactions occur well in the gasification reactor with long residence time or duration for biomass, temperature, and pressure.

\subsection{Gasifier types and selection}

Gasifier or gasification reactor is a media where the gasification process takes place. In general, gasifiers can be divided into three main types, namely fixed or moving bed, fluidized bed, and entrained flow[3]. According to[18], fluidized bed gasifier is the most suitable type of gasifier to produce bio-syngas which is then converted again into fuel. According to [19] the fluidized bed gasifier has an advantage in terms of mixing of gases and more efficient solids, increased reaction and conversion rates, and a lower tar content in the generated gas producer or raw syngas. There are two types of fluidized bed gasifier, namely bubbling fluidized bed (BFB) and circulating fluidized bed (CFB). According to [3]CFB gasifiers are interesting enough to be applied to biomass compared to BFB gasifiers that were first developed for coal gasification. CFB gasifiers have longer residence time and are suitable to be applied for high volatile inlet feed, where biomass has a higher volatile content when compared to coal [21]. Fig.1 shows a gasifier scheme of CFB type.

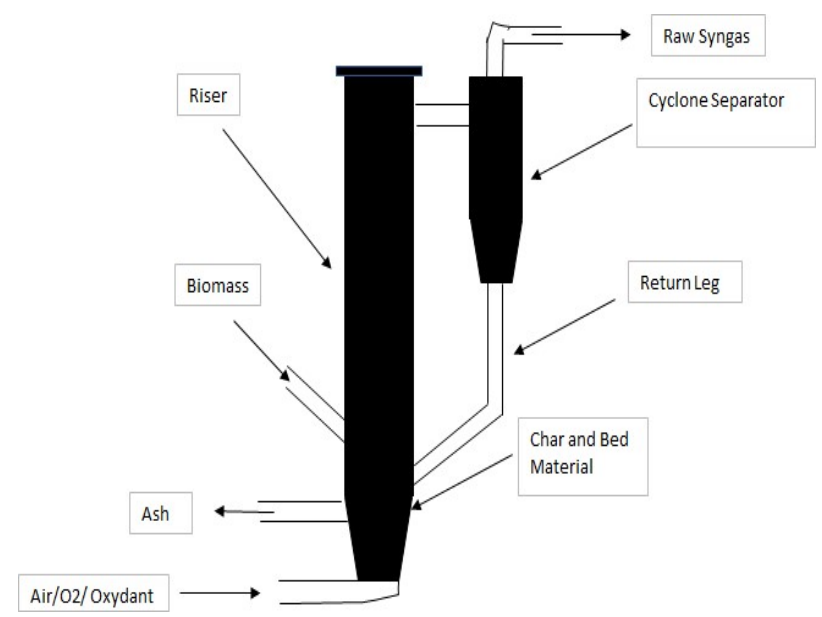

Fig. 1. Circulating Fluidized Bed Gasifier Schematic[20]

\subsection{Process Simulation}

The simulation was done by using Aspen Hysysprocess simulator. Aspen Hysys has been used in several studies to simulate biomass gasification [11][12][22]. Aspen Hysys is a process simulator that uses operating unit blocks such as reactors, heat exchangers, pumps, and so on. Operating unit blocks are placed on the flowsheet to specify the flow of energy and material. The physics property database that is in the Aspen Hysys is used for simulation calculations. The various components that comprise Aspen Hysys provide an extremely powerful approach to steady state process modeling. The user describes the process in terms of pieces of equipment interconnected by process stream, and the program solves all the mass/energy/equilibrium equations, taking into consideration the specified design for the units [23]. Feedstock EFB is not a default component in Aspen Hysys and must be put manually as Solid Hypothetical component. The input of EFB as hypothetical solid component was based on ultimate analysis of EFB measured.

EFB feedstock based for simulation is dry ash free (daf) base. From weight percentage of components C, H, $\mathrm{O}, \mathrm{N}, \mathrm{S}$.

\section{Methodology}

The model is divided into few blocks of unit operation, including biomass breakdown, pyrolysis, gasification, and solid recirculation. The block flow diagram (BFD) of the gasification process shown on Fig.2, while process flow diagram (PFD) of simulation in Aspen Hysys shown on Fig.3.

Assumption made for the simulation are:The process is steady state[12][24]instantaneous devolatilization after EFB entering CFB gasifier[12][24]the process in the gasifier is Isothermal[12][21], Char is $100 \%$ carbon[20], All sulphur reacts to form $\mathrm{H}_{2} \mathrm{~S}$ [20], $\mathrm{N}_{2}$ reaction is only forming $\mathrm{NH}_{3}[17]$, tar formation is ignored because relatively high operating temperature[22], Syngas is produced by the gasifier at the chemical equilibrium[25]. EFB is modelled on dry ash free (daf) basis for 
simplicity[12], therefore biomass char contains carbon only[12], cyclone separation efficiency is $85 \%[20]$, Carbon conversion at $96 \%[26]$, Carbon loss is assumed at $2 \%[13]$, heat loss is neglected.

There are 6 steps involved in the simulation:

\subsection{Biomass Feedstock}

Feedstock used is Empty Fruit Bunch (EFB) as a waste product of Crude Palm Oil (CPO) production. The composition of the EFB is based on dry ash free base (daf) taken from [6]. Table 1 displaythe composition of feedstock based on ultimate analysis and dry ash free basis (daf).Based on ultimate analysis chemical formula can be determined [22]. In 100 grams of biomass, there is 51.67 grams of carbon. Mass in grams divided by carbon molecular weight $(12 \mathrm{~g} / \mathrm{mol})$ will give result of $4.306 \mathrm{~mol}$ of carbon. The same is applied to other elements which lead to the following chemical formula for EFB Biomass: $\mathrm{C}_{4.306} \mathrm{H}_{6.176} \mathrm{O}_{2.587} \mathrm{~N}_{0.048} \mathrm{~S}_{0.003}$, and this chemical formula isused as an input to AspenHysysas hypothetical solid component.

\subsection{Simulation Basis Manager}

Simulation Basis Manager (SBM) is the welcome interface for a simulation project in Aspen Hysys and helps mainly in selecting and defining pure components,assigning a property package for carrying out flash and physical properties calculations. The fluid package chosen was Peng - Robinson equation of state (EOS)[12]. The gasification reaction was modelled as equilibrium reactions [25], the thermodynamic equilibrium model predicts the maximum achievable yield.

Table 1. Ultimate analysis and dry ash free (daf) basis [24]

\begin{tabular}{lcc}
\hline & $\begin{array}{c}\text { \% Wt. As } \\
\text { received }\end{array}$ & $\begin{array}{c}\text { \% Wt. Dry ash free } \\
\text { (calculated) }\end{array}$ \\
\hline $\mathbf{C}$ & 26.94 & 51.67 \\
$\mathbf{H}$ & 3.22 & 6.18 \\
$\mathbf{O}$ & 21.58 & 41.39 \\
$\mathbf{N}$ & 0.35 & 0.67 \\
$\mathbf{S}$ & 0.05 & 0.10 \\
Water & 44.6 & \\
Ash & 3.26 & \\
\hline
\end{tabular}

\subsection{Process Description}

Gasification of EFB is simulated in three main stages, which is biomass breakdown, gasification, and solid recirculation.Its process can be split into three linked processes: pyrolysis, gasification, and partial combustion. The one that provide heat for entire reaction is partial combustion, because its supplied heat required by the gasification reactions [27]. Oxidant used was pure oxygen andsteam. Both streams determine operating pressure of the gasifier. Constant operating condition stated on table 4.

The EFB quickly undergo pyrolysis in thegasifier, with reaction:

$\mathrm{C}_{4.306} \mathrm{H}_{6.176} \mathrm{O}_{2.587} \mathrm{~N}_{0.048} \mathrm{~S}_{0.003} \longrightarrow 4.306 \mathrm{C}+$
$3.088 \mathrm{H}_{2}+1.2935 \mathrm{O}_{2}+0.024 \mathrm{~N}_{2}+0.003 \mathrm{~S}$

The resulting compounds subsequently react in the gasifier as tabulated on table 2 .

Table 2. Gasification Reactions[20]

\begin{tabular}{|c|c|c|}
\hline Reaction & $\begin{array}{l}\Delta \mathrm{H}_{\mathrm{r}} \\
(\mathrm{MJ} / \mathrm{mol}) \\
\text { (a) } 25^{\circ} \mathrm{C}\end{array}$ & $\begin{array}{l}\text { Reaction } \\
\text { Number }\end{array}$ \\
\hline $\mathrm{C}+0.5 \mathrm{O}_{2} \mathrm{CO} \longrightarrow$ & -111 & (R2) \\
\hline $\mathrm{C}+\mathrm{CO}_{2} 2 \mathrm{CO} \longrightarrow$ & 172 & (R3) \\
\hline $\mathrm{C}+\mathrm{H}_{2} \mathrm{O} \leftrightharpoons \mathrm{CO}+\mathrm{H}_{2}$ & 131 & (R4) \\
\hline $\mathrm{C}+2 \mathrm{H}_{2} \mathrm{CH}_{4} \longmapsto$ & -75 & (R5) \\
\hline $\mathrm{CO}+0.5 \mathrm{O}_{2} \longrightarrow \mathrm{CO}_{2}$ & -283 & (R6) \\
\hline $\mathrm{H}_{2}+0.5 \mathrm{O}_{2} \longrightarrow \mathrm{H}_{2} \mathrm{O}$ & -242 & (R7) \\
\hline $\mathrm{CO}+\mathrm{H}_{2} \mathrm{O} \longleftrightarrow \mathrm{CO}_{2}+\mathrm{H}_{2}$ & -41 & (R8) \\
\hline $\begin{array}{l}\mathrm{CH}_{4} \\
3 \mathrm{H}_{2}\end{array}+\mathrm{H}_{2} \mathrm{O} \longleftrightarrow \mathrm{CO}+$ & 206 & (R9) \\
\hline $\mathrm{H}_{2}+\mathrm{S} \longrightarrow \mathrm{H}_{2} \mathrm{~S}$ & -300 & (R10) \\
\hline $0.5 \mathrm{~N}_{2}+1.5 \mathrm{H}_{2} \longleftrightarrow \mathrm{NH}_{3}$ & -91 & (R11) \\
\hline
\end{tabular}

\subsection{Simulation Description}

The gasification of EFB was simulated according to sequence shown on the Process Flow Diagram (PFD) on Fig. 3.

\subsubsection{Biomass Breakdown}

Breakdown of EFB was simulated in conversion reactor "Breakdown". EFB breakdown closely represent a pyrolysis process in gasifier. Biomass breakdown into its constituting conventional elements of Carbon (C), Hydrogen (H), Nitrogen (N), Oxygen (O), and Sulphur (S). Pyrolysis reaction involved was R1. Char from EFB breakdown consist of a pure carbon, it was simulated as bottom products of conversion reactor "Breakdown". Bottom product as a solid contains char and sulphur. Tee-101 block simulating carbon separation, whereas $96 \%$ of carbon was converted, while remaining $4 \%$ unconverted and circulated on cyclone separator. The sulphur was reacting with hydrogen and modelled as separate conversion reaction. The sulphur split from carbon on X-101 component splitter block. 


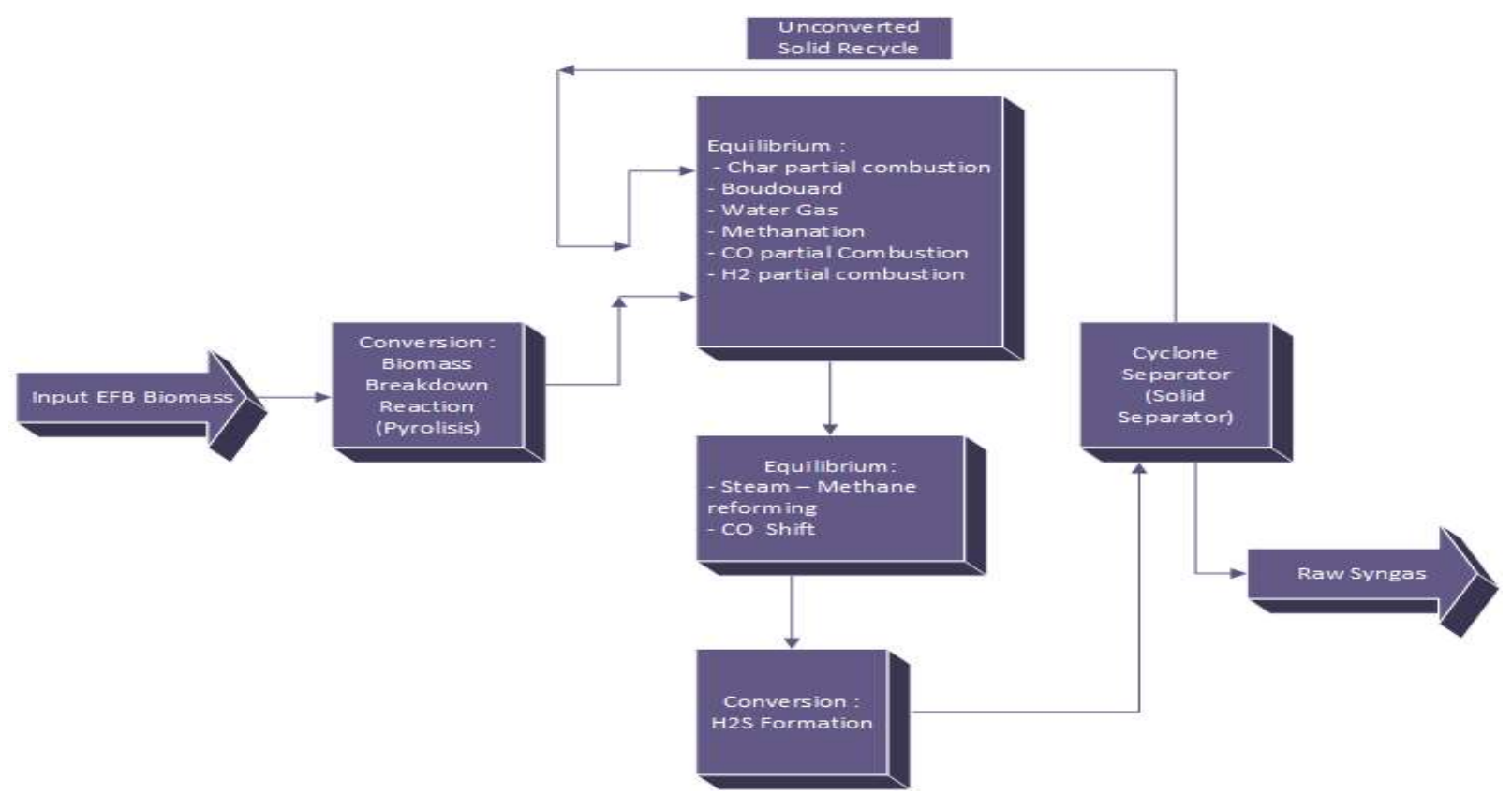

Fig. 2. Block Flow Diagram of Gasification in CFB Gasifier

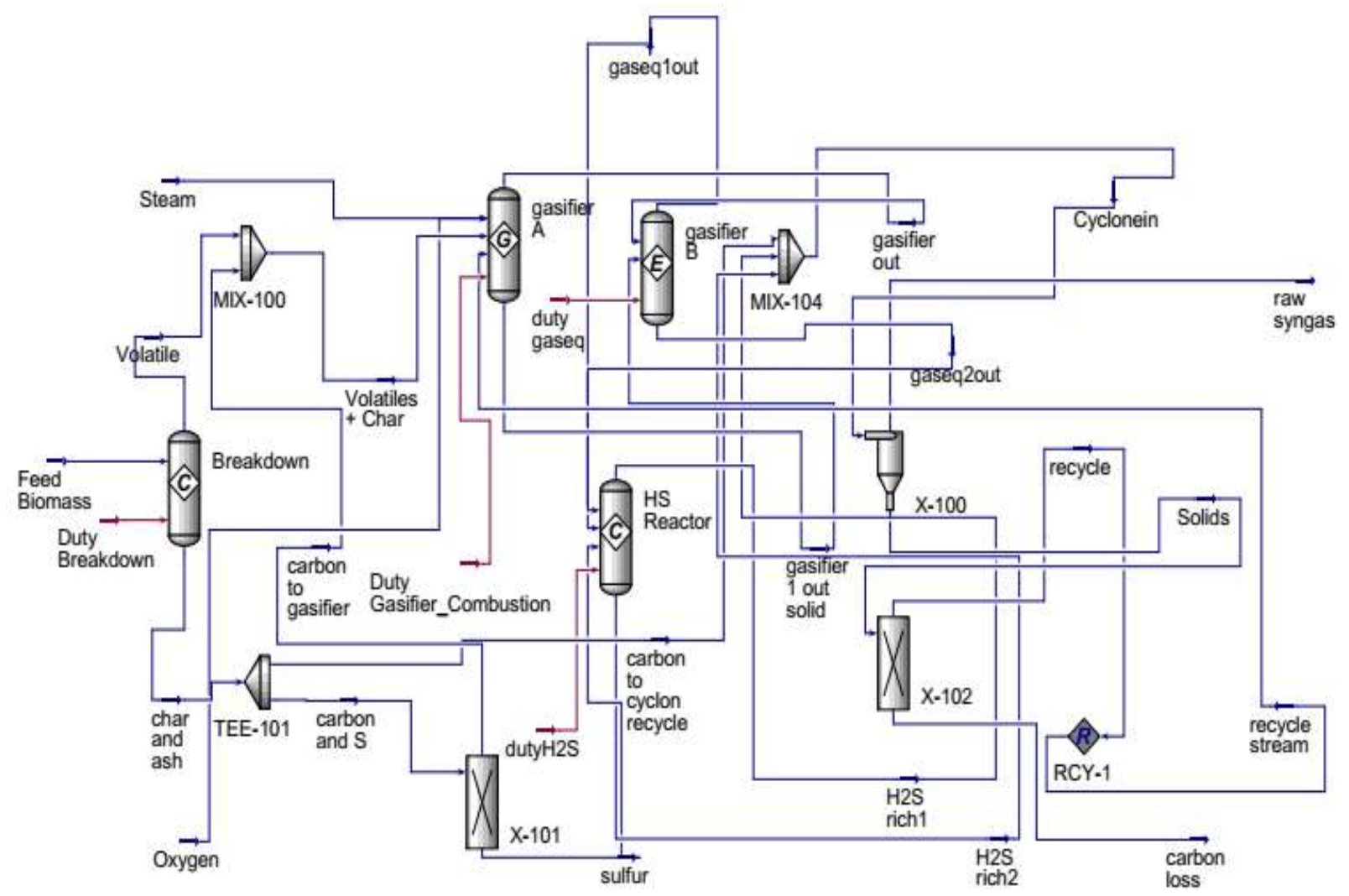

Fig. 3. Aspen Hysys steady state simulation process flow diagram

\subsubsection{Gasification}

The product of conversion reactor "Breakdown", which is conventional elementsreactedwith oxygen and steam at gasifier. The product streams of conversion reactor "Breakdown" are volatiles and carbon to gasifier.
Streams "volatile" and "carbon to gasifier"connected to a feed of "gasifier A". The mechanism of gasification involves complexcollection of various reaction during real gasification process, however the gasification reactionswere simplified into major reactions as listed on table 2. Reaction R2until R7occurred on "gasifier A" and modelled as equilibrium reaction in Gibbs reactor. 
The reactions using Gibbs free energy minimisation methodto find equilibrium constant. Equilibrium constant through Gibbs free energy minimisation was calculated by Aspen Hysys.Reactions R8 and R9 occurred on "gasifier B" as equilibrium reaction, where default data of equilibrium constant vs temperature was provided by Aspen Hysys. Gasification process modelled on both "gasifier A" and "gasifier B" as a set of equilibrium reactions. The gasification on "gasifier A" modelling the pyrolysis and char combustion. Reaction on "gasifier B"modelling CO shift conversion and Steam $-\mathrm{CH}_{4}$ reforming reaction using equilibrium method in equilibrium reactor. The entire streams outlet "gasifierB", which are stream"gaseq1out" and "gaseq2out"passed through "HS reactor" which models the conversion of solid sulphur into hydrogen sulphide $\left(\mathrm{H}_{2} \mathrm{~S}\right)$ with a conversion reactor assuming complete conversion, since sulphur does not have equilibrium constant embedded in Aspen Hysys and the reaction itself is non-equilibrium.

\subsubsection{Unreacted Solid Separation}

Products from "HS reactors" on stream " $\mathrm{H}_{2} \mathrm{~S}$ rich1" and " $\mathrm{H}_{2} \mathrm{~S}$ rich2" passed cyclone separator "X-100" to separate unconverted solid carbon with $85 \%$ efficiency. Bottom outlet of "X-100" contains solid only,went to "X-102" that split solid stream into recycle stream that was sent back to the "gasifier A", and another stream named "carbon loss"was the loss of the solid carbon. Top outlet of "X-100" is the raw syngas products.

\subsection{Model Validation}

Validation of model developed was carried out by adapting work of [28] about HTW Winkler Gasifier CFB gasifier for coal gasification. Important operating parameters adapted from [28] listed on table 3. German lignite weight percentage of ultimate analysis daf to be used as Aspen Hysishypothetical solid input were: $\mathrm{C}=$ $68 \%, \mathrm{H}=4.9 \%, \mathrm{O}=25.7 \%, \mathrm{~N}=0.7 \%, \mathrm{~S}=0.6 \%$. The steam to biomass ratio $(\mathrm{S} / \mathrm{B})$ was assumed at 0.37 . Cold gas efficiency (CGE) is calculated by using (1). Formula was obtained from [20]. HHV value of German lignite (daf base) was taken from [29] at 25,610 kJ/kg.

Table 3. Operating parameters of HTW Winkler gasifier [28]

\begin{tabular}{lr}
\hline Parameter & Value \\
\hline CFB Gasifier Operating Temperature $\left({ }^{\circ} \mathrm{C}\right)$ & 900 \\
Operating Pressure $(\mathrm{kPa})$ & 1000 \\
$\begin{array}{l}\text { German Lignite Feed Flowrate }(\mathrm{kg} / \mathrm{h}) \\
\begin{array}{l}\text { Oxygen to Biomass }(\mathrm{O} / \mathrm{B}) \text { ratio }\left(\mathrm{Nm}^{3} / \mathrm{kg}\right. \\
\text { biomass })\end{array}\end{array}$ & 23200 \\
\hline
\end{tabular}

$$
C G E=\frac{\dot{m}_{\text {gas }} \cdot H H V_{\text {gas }}}{\dot{m}_{\text {fuel }} \cdot H H V_{\text {fuel }}}
$$

Where $\dot{m}_{\text {gas }}$ is flow rate of product gas in $\mathrm{kg} / \mathrm{h}$, $\dot{m}_{\text {fuel }}$ is flow rate of Biomass in $\mathrm{kg} / \mathrm{h} . \mathrm{HHV}_{\text {gas }}$ and $\mathrm{HHV}_{\text {fuel }}$, are the high heating value (in $\mathrm{kJ} / \mathrm{kg}$ ) of the gas and fuel respectively.

\subsection{Sensitivity Analysis}

Sensitivity analysis toward operating parameters such as temperature, steam to biomass ratio $(\mathrm{S} / \mathrm{B})$, equivalence ratio (ER), and gasifying ratio were carried out. The purpose is to obtain optimum gasification operating parameters in CFB gasifier. Details of the parameters to be analysed as follows.

1. Temperature effect. The temperature was varied from $600{ }^{\circ} \mathrm{C}$ to $1400{ }^{\circ} \mathrm{C}$ and the effect toward syngas yield, $\mathrm{CO}_{2}$ formation, $\mathrm{CH}_{4}$ formation, and $\mathrm{H}_{2} / \mathrm{CO}$ ratio is analysed.

2. Steam to biomass ratio $(\mathrm{S} / \mathrm{B})$ effect. The ratio was varied from 0 to 2.1. Its effect toward syngas yield, $\mathrm{CO}_{2}$ formation, $\mathrm{CH}_{4}$ formation, and $\mathrm{H}_{2} / \mathrm{CO}$ ratio is analysed. Formula to calculate $\mathrm{S} / \mathrm{B}$ shown by (2) and obtained from [22].

$$
\frac{S}{B}=\frac{\dot{M}_{\text {steam inlet gasifier }\left(\frac{k g}{h}\right)}}{\dot{M}_{\text {biomass inlet gasifier }}\left(\frac{k g}{h}\right)}
$$

Where, $\dot{M}_{\text {steam inlet gasifier }}=$ Molar flow of the steam inlet to gasifier, $\dot{M}_{\text {biomass inlet gasifier }}=$ Molar flow of the inlet biomass to gasifier.

3. Equivalence Ratio (ER) effect. The ER wasvaried from 0.2 to 1 . Its effect toward syngas yield, $\mathrm{CO}_{2}$ formation, and $\mathrm{CH}_{4}$ formation was analysed. Formula to calculate ER is shown by (3) and obtained from [22].

$$
E R=\frac{\dot{m}_{\text {oxygen }}\left(\frac{k g}{h}\right)}{\dot{m}_{\text {oxygen stoichiometri }}\left(\frac{k g}{h}\right)}
$$

Where, $\dot{m}_{\text {oxygen }}=$ Actual oxygen inlet to gasifier, $\dot{m}_{\text {oxygen stoichiometri }}=$ mass of oxygen inlet for stoichiometry combustion in the gasifier.

4. Effect of S/B and ER simulated simultaneously. Its effect toward syngas yield, $\mathrm{CO}_{2}$ formation, and $\mathrm{CH}_{4}$ formation is analysed.

The pressure was maintained at constant value throughout the simulation, the operating parameters used were shown in table 4.

Table 4. Constant Operating Parameters

\begin{tabular}{lr}
\hline Parameter & Value \\
\hline Oxygen inlet Temperature $\left({ }^{\circ} \mathrm{C}\right)[22]$ & 600 \\
Operating Pressure $(\mathrm{kPa})[28]$ & 1000
\end{tabular}


Oxygen molar percentage $(\%)^{*}$

100

EFB Feed Flowrate $(\mathrm{kg} / \mathrm{h})[6]$

6160

Steam Inlet Temperature $\left({ }^{\circ} \mathrm{C}\right)[22]$

800

* Oxygen concentration is assumed at $100 \% \mathrm{~mol}$, though actual purity that can be achieved is $99.6 \%$ [30]

\section{Result and Discussion}

\subsection{Validation of CFB Gasifier Model}

Feedstock Chemical formula is $\mathrm{C}_{5.667} \mathrm{H}_{4.9} \mathrm{O}_{1.606} \mathrm{~N}_{0.7} \mathrm{~S}_{0.6}$. Chemical formula obtained by using calculation found in [22]. Result of the validation summarized on table 5 .

Table 5. Comparison of the product gas compositions from model and data reference from [28]

\begin{tabular}{lrrrrr}
\hline \multirow{2}{*}{ Sources } & \multirow{5}{*}{ CGE (\%) } & \multicolumn{5}{c}{ * } \\
\cline { 3 - 6 } & & H2 & CO & CO2 & CH4 \\
\hline$[28]$ & 85 & 34 & 45 & 17 & 4 \\
$\begin{array}{l}\text { Model } \\
\text { prediction }\end{array}$ & 73 & 34 & 46 & 20 & 1 \\
\hline
\end{tabular}

$* \mathrm{Vol} \%=\mathrm{mol} \%$ at high operating temperature (Ideal gas)

The model prediction particularly for $\mathrm{CO}$ and $\mathrm{H}_{2}$ composition agreed with the reference data. CGE as result of simulation was lower than actual CGE from HTW Winkler gasifier methanol plant data [28]. Model prediction $\mathrm{CO}_{2}$ and $\mathrm{CH}_{4}$ slightly less accurate. More complications of reaction may happen during real gasification process by using HTW Winkler gasifier. Based on tabulated result, $\mathrm{CH}_{4}$ under or over prediction is a common problem for modellers [20][26]. Lower CGE prediction obviously seen as an effect of higher $\mathrm{CO}_{2}$ content.

\subsection{Effect of The Reactor Temperature}

Temperature of the reactors (gasifier A and gasifier B) varied from $600{ }^{\circ} \mathrm{C}$ to $1400{ }^{\circ} \mathrm{C}$. The value of Equivalence Ratio (ER) was set at $\mathrm{ER}=0.6$ [22] and Steam to Biomass EFB ratio $(\mathrm{S} / \mathrm{B})$ was set at $\mathrm{S} / \mathrm{B}=0.23$ [22]. Based on Fig.4, temperature is giving significant effect toward syngas $\left(\mathrm{CO}+\mathrm{H}_{2}\right)$ production, once temperature increase, the yield of syngas is increase, and at temperature above $800{ }^{\circ} \mathrm{C}$, syngas yield experiences no significant increase. From fig. 4 it is shown that once temperature increasing, $\mathrm{CO}_{2}$ content is decreasing. $\mathrm{CO}_{2}$ formation is described by reaction $\mathrm{R} 6$ and $\mathrm{R} 8 . \mathrm{CO}_{2}$ decreases rapidly from $600{ }^{\circ} \mathrm{C}$ to $800{ }^{\circ} \mathrm{C}$, and then decreases slowly. The most interesting point, when $\mathrm{CO}_{2}$ decreases rapidly, $\mathrm{CO}$ increases rapidly. At temperature above $800{ }^{\circ} \mathrm{C}$, it is almost no significant effect to yield $\mathrm{CH}_{4}$, while yield of $\mathrm{H}_{2}$ slightly affected. The higher the temperature, the higher the carbon conversion efficiency as can be seen on the $\mathrm{CO}$ yield at high temperature.
Optimum temperature is at $800{ }^{\circ} \mathrm{C}$, where $\mathrm{H}_{2}$ is at its highest yield.

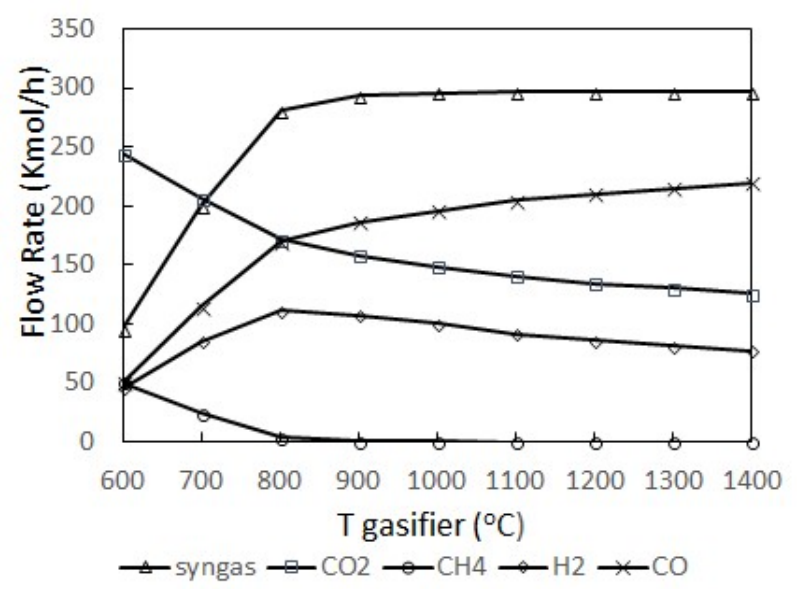

Fig. 4. Effect of the gasifier temperature on thesyngas

High temperature will give more syngas yield, on the contrary, ratio of $\mathrm{H}_{2}$ to $\mathrm{CO}$ will drop, as shown on Fig.5. this phenomenon occurs because high temperature favours endothermic reaction [20]. Reaction involving $\mathrm{CO}$ is all endothermic, therefore high reactor temperature tend to shift more on the $\mathrm{CO}$ production either as product or reactant, especially for reactions R3, R4, R8 and R9.

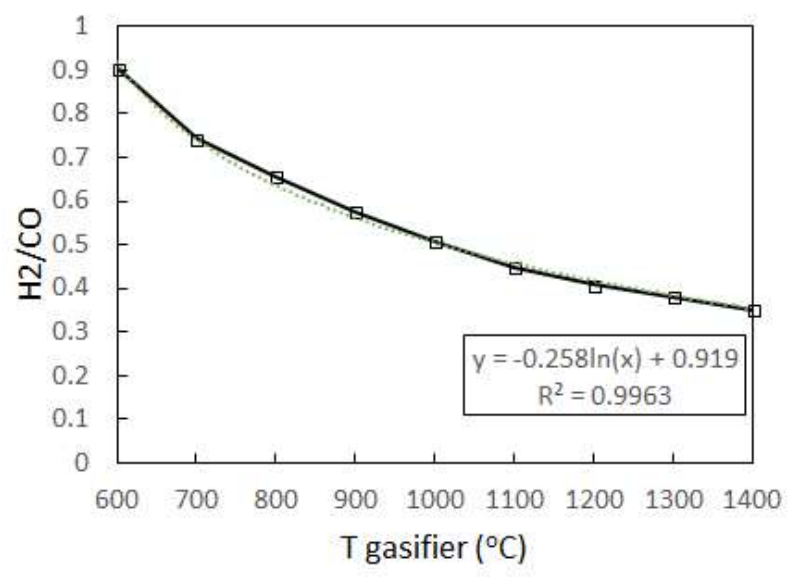

Fig. 5. Effect of the gasifier temperature on the $\mathrm{H}_{2} / \mathrm{CO}$

The equation in Fig.5 was obtained by adding Microsoft Excel trendline into plot of $\mathrm{H}_{2} / \mathrm{CO}$ data vs reactor temperature data. The data patternsshow exponential tendency, hence trendline added was exponential trendline, and value of $\mathrm{R}^{2}$ showed value 0.9963 which indicating that the data fits with the exponential line.

For $\mathrm{H}_{2}$ formation reactions occur wasreactions $\mathrm{R} 4$ and R9 only.At high temperature, more $\mathrm{CO}$ produced, and less $\mathrm{H}_{2}$ produced as shown in Fig.4, and then $\mathrm{H}_{2} / \mathrm{CO}$ value will decreasewhen temperature increases as shown on Fig.5. $\mathrm{CH}_{4}$ content is decreasing at higher temperature, due to endothermic reaction (R8). $\mathrm{CH}_{4}$ formation is unwanted because it makesthe 
efficiency of syngas becomes lower[22].Yield of syngas is higher at high temperature, but ash softening temperature must be avoided to prevent particle agglomeration[28]. Correlation between gasification temperature and $\mathrm{H}_{2} / \mathrm{CO}$ can be represented by equation shown on Fig. 5, which shows a logarithmic relationship between $\mathrm{H}_{2}$ /CO versus gasifier temperature.

\subsection{Effect of the steam to biomass ratio}

The ratio of steam to biomass (S/B) affects the production of syngas. S/B can be calculated by using (2).Impact of $S / B$ has been investigated by varying $S / B$ value between 0 to 2.1 with interval 0.3 . Operating temperature was set at $\mathrm{T}=900{ }^{\circ} \mathrm{C}[28]$ and $\mathrm{ER}=$ $0.6[22]$. Higher the value of $\mathrm{S} / \mathrm{B}$, the more $\mathrm{H}_{2}$ produced, as shown on Fig.6. While for the COproduced it isinversely proportional with S/B.Increase on $\mathrm{CO}_{2}$ composition in product gas is due to water gas shift reaction ( $\mathrm{R} 8$ ), which is exothermic that prefer $\mathrm{CO}_{2}$ as product together with $\mathrm{H}_{2}$. The production of $\mathrm{CH}_{4}$ is very lowsince $\mathrm{CFB}$ gasifier operating athigh temperature. From Fig.7, S/B ratio optimum is at 0.4 to 0.5 , for ratio of $\mathrm{H}_{2}$ to $\mathrm{CO}\left(\mathrm{H}_{2} / \mathrm{CO}\right)=1$.

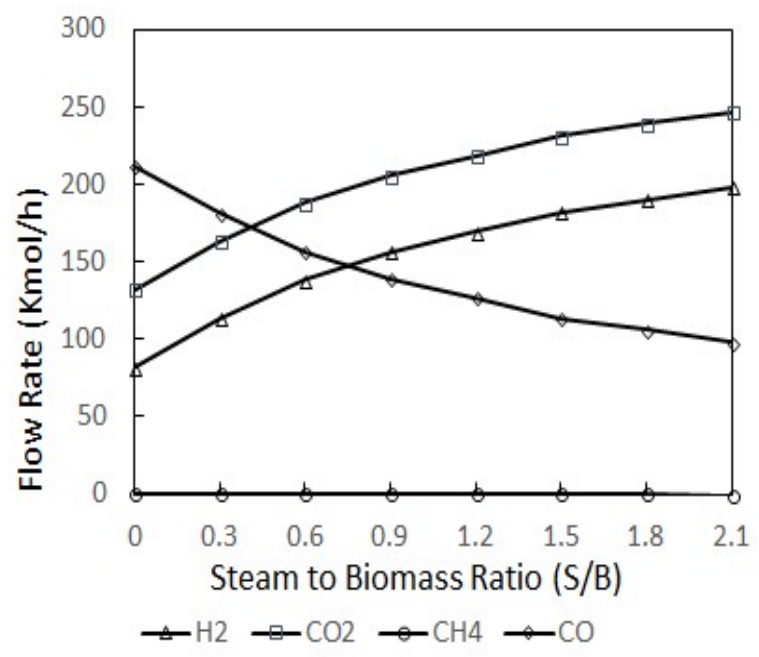

Fig. 6. Effect of the $\mathrm{S} / \mathrm{B}$ on the syngas product

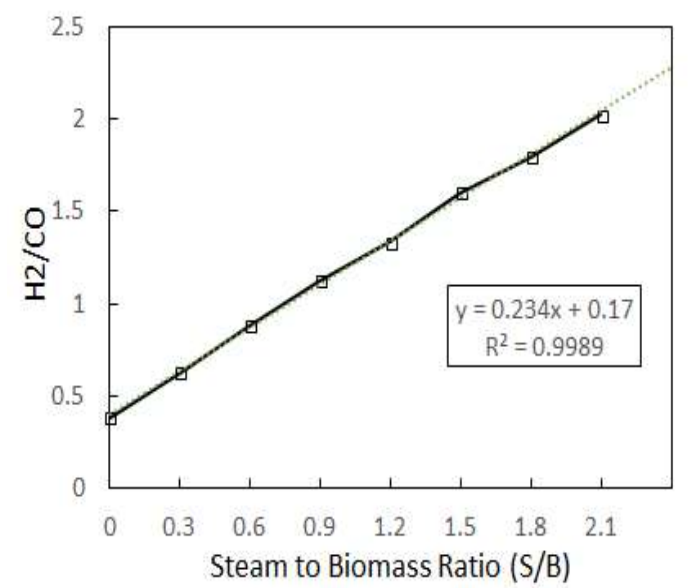

Fig. 7. Effect of the $\mathrm{S} / \mathrm{B}$ on the $\mathrm{H}_{2} / \mathrm{CO}$
Fig.7 shows that $\mathrm{S} / \mathrm{B}$ has significant effect to the $\mathrm{H}_{2} / \mathrm{CO}$ ratio. As can be seen, $\mathrm{H}_{2} / \mathrm{CO}$ directly proportional with the $\mathrm{S} / \mathrm{B}$, when $\mathrm{S} / \mathrm{B}$ increase, $\mathrm{H}_{2} / \mathrm{CO}$ increases as well. This phenomenon can be explained with $\mathrm{R} 4, \mathrm{R} 8$, and $\mathrm{R} 9$, where the formation of $\mathrm{H}_{2}$ products correlates with the $\mathrm{H}_{2} \mathrm{O}$ as the reactant. Steam itself is $\mathrm{H}_{2} \mathrm{O}$ vapor, and $\mathrm{S} / \mathrm{B}$ correlates with the steam amount involved on the reaction. The more steam involved in the reaction, the more $\mathrm{H}_{2}$ and $\mathrm{CO}_{2}$ produced. correlation between $\mathrm{H}_{2} / \mathrm{CO}$ vs $\mathrm{S} / \mathrm{B}$ is represented by equation on Fig.7.

The equation in Fig. 7 which is based on plot of $\mathrm{H}_{2} / \mathrm{CO}$ data vs Steam to biomass ratio data shows linear pattern, therefore by adding Microsoft Excel linear trendline, the equation can be derived. The equation has $\mathrm{R}^{2}=0.9989$ which indicating that the data fit with the linear trendline added.

\subsection{Effect of The Equivalence Ratio}

The quantity of $\mathrm{O}_{2}$ for gasification is quantified by the Equivalence Ratio (ER). ER value for gasification reaction is below 1, while if ER value greater than 1, the reaction becomes combustion reaction [3].

Stoichiometric quantity of oxygen can be determined by increasing quantity of oxygen inlet in Aspen Hysysprogressively with $\mathrm{S} / \mathrm{B}=0$. Based on simulation, for the flow rate of EFB biomass at $6.16 \mathrm{ton} / \mathrm{h}$, the requirement of stoichiometric oxygen is $11,860 \mathrm{~kg} / \mathrm{h}$. The value of ER below 1 is desired since the focus is to get $\mathrm{CO}$ as gasification product. Oxygen inlet is at the same pressure with gasifier operating pressure at 1000 $\mathrm{kPa}$. The influence of ER to syngas flowrate and outlet gas composition is simulated with value of $\mathrm{S} / \mathrm{B}=1.5$ and gasifier temperature at $900{ }^{\circ} \mathrm{C}$. ER value was varied from 0 to 1 with 0.1 interval.

Fig. 8 shows that $\mathrm{CO}_{2}$ production is increase whenever ER value increases. $\mathrm{CO}_{2}$ production must be minimum, to make carbon loss on the gasification process becomes minimum, therefore optimum ER value should be chosen at value below 1 . ER value should be selected at value below 1 in combination with $S / B$ value. It is shown on Fig. 8 that the amount of $\mathrm{H}_{2}$ will decrease when ER value increasing until 1. From Fig.9 at ER = 1, $\mathrm{H}_{2} / \mathrm{CO}$ becomes 0 , which means no more $\mathrm{H}_{2}$ and $\mathrm{CO}$ produced, and only $\mathrm{CO}_{2}$ is produce at $\mathrm{ER}=1$, which demonstrating that the reaction is combustion reaction. At $\mathrm{ER}=0$, there is still gasification reaction due to steam still utilized as an oxidant. The gasification reaction was steam gasification. 


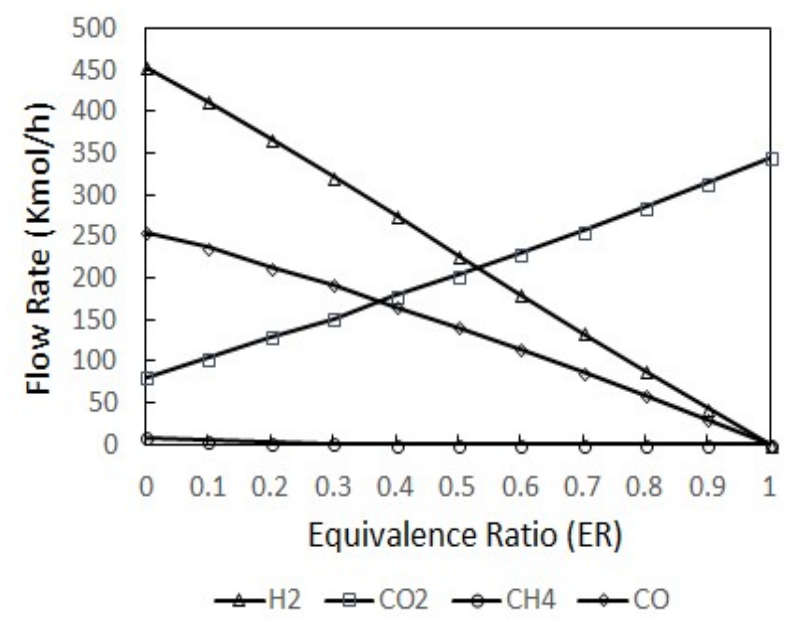

Fig. 8. Effect of the ER on syngas product

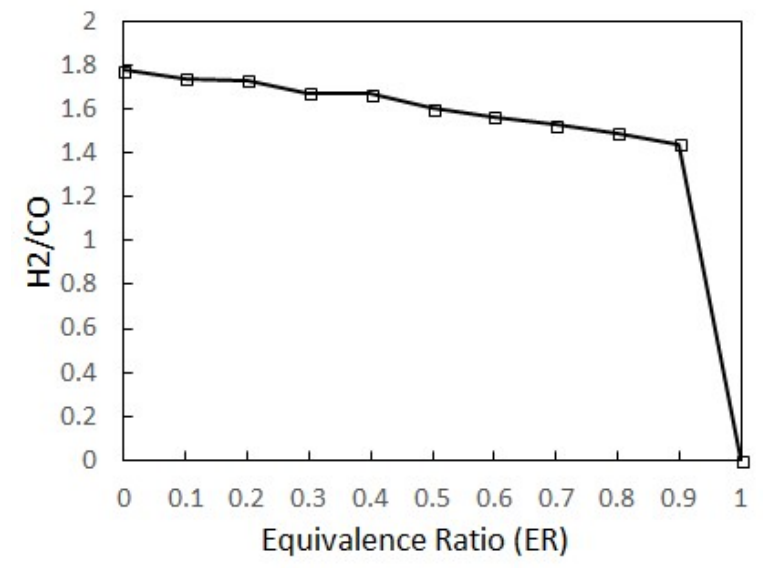

Fig. 9. Effect of the ER on the $\mathrm{H}_{2} / \mathrm{CO}$

Fig. 9 confirms that gasification reaction should have $\mathrm{ER}=1$. If $\mathrm{ER}$ value is more than 1, the reaction is complete combustion which resulting on $\mathrm{CO}_{2}$ and $\mathrm{H}_{2} \mathrm{O}$ and other gasses. It is shown that ER value will give optimum result at smaller ER, but ER value will correspond with partial oxidation of char, and if too small, insufficient $\mathrm{O}_{2}$ for oxidation reaction happened.

\subsection{Effect of the GasifyingAgent}

Fig. 10 shows that by varying gasification agent (S/B and ER) has significant effect toward product gas composition. When gasification done without oxygen $(\mathrm{S} / \mathrm{B}=0.9 ; \mathrm{ER}=0)$, and only using steam as oxidant and gasifying agent, the yield of $\mathrm{CO}$ and $\mathrm{H}_{2}$ is big enough, but $\mathrm{CH}_{4}$ also exist in considerable amount.As mentioned above, $\mathrm{CH}_{4}$ is unwanted because it will lower the efficiency and to minimize $\mathrm{CO}_{2}$ content, more oxygen is needed. If no steam or water involved in the gasification reaction and only pure oxygen used as an oxidant, products gasses mostly contain $\mathrm{CO}$ and $\mathrm{CH}_{4}$.

When gasification done with oxygen and steam (S/B $=0.9 ; \mathrm{ER}=0.2)$ there is significant reduction on $\mathrm{CH}_{4}$ content, but $\mathrm{CO} 2$ increases. Chemical or Liquid Fuel synthesis requires both steam and $\mathrm{O}_{2}$ as an oxidant[31].

When gasification done without steam $(\mathrm{S} / \mathrm{B}=0 ; \mathrm{ER}$ $=0.2$ ), there are only $\mathrm{CO}$ and $\mathrm{CH}_{4}$ yield, no $\mathrm{H}_{2}$ produced. Without $\mathrm{H}_{2}$, gasification route by using $\mathrm{O} 2$ only is not suitable for chemical and fuel synthesis.

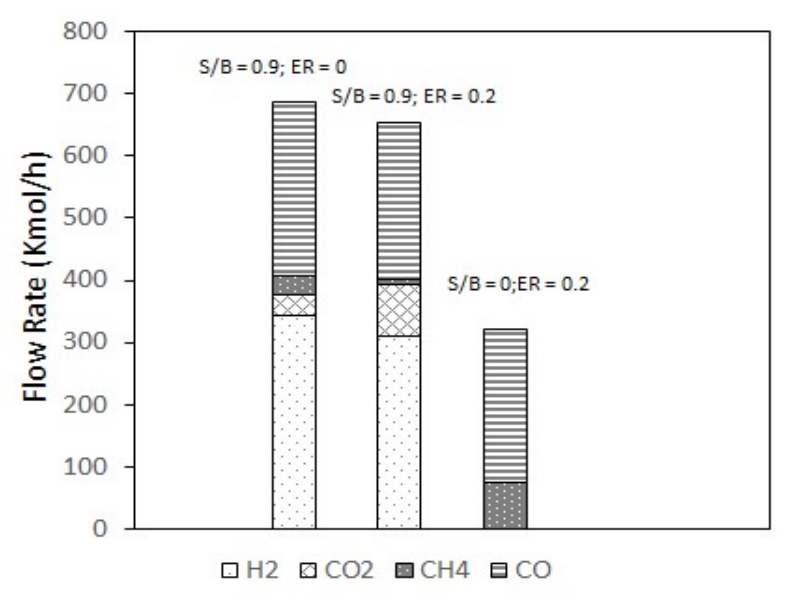

Fig. 10. Effect of gasifying agent on the syngas

Based on sensitivity analysis above, optimum temperature result for this model that gave highest $\mathrm{H}_{2}$ content on the product syngas is higher than the one given by [13], where the optimum temperature was at 650 to $700{ }^{\circ} \mathrm{C}$. The study conducted by [16] showed no significant effect of temperature increase to $\mathrm{H}_{2}$ yield, thereforethis study is more similar the study of [13]. The study conducted by [12] showed increase in syngas yield when gasifier temperature increases, but the maximum gasifier temperature limited only until $800{ }^{\circ} \mathrm{C}$. This study revealed that optimum temperature where highest yield of $\mathrm{H}_{2}$ achieved is at $800^{\circ} \mathrm{C}$, and $\mathrm{H}_{2} / \mathrm{CO}$ optimum ratio at $800{ }^{\circ} \mathrm{C}$ is 0.65 . Since the purpose of this study is not specifically targeting $\mathrm{H}_{2}$, optimum temperature could be anywhere above $800{ }^{\circ} \mathrm{C}$, and $\mathrm{H}_{2} / \mathrm{CO}$ ratio depends on the requirement of further process (Chemical synthesis, power generation, $\mathrm{H} 2$ production, etc), and adjustment on the $\mathrm{H}_{2} / \mathrm{CO}$ will be done through water - gas shift (WGS) reaction on WGS reactor[22].This paper showed the importance of $\mathrm{H}_{2} / \mathrm{CO}$ ratio as the model developed in simulation for further simulation of chemical synthesis based on EFB gasification. This paper discussed temperature effect, equivalence ratio effect, steam to biomass ratio effect, and gasifying agent (steam to biomass ratio and Equivalence ratio simulated at the same time).

The effect of S/B shown on Fig.6 is very important to the production of $\mathrm{H}_{2}$ rich syngas, the more steam introduced into gasifier, the more $\mathrm{H}_{2}$ rich syngas produced. Besides $\mathrm{H}_{2}$, higher $\mathrm{S} / \mathrm{B}$ affects $\mathrm{CO}_{2}$ content on product syngas, when $\mathrm{S} / \mathrm{B}$ increase, the $\mathrm{CO}_{2}$ content increases as well. $\mathrm{S} / \mathrm{B}$ ratio should be balanced by low ER value to control $\mathrm{CO}_{2}$ formation, low ER value is desired to lower $\mathrm{CO}_{2}$ content, as shown on Fig.10, but if $\mathrm{CH}_{4}$ formation need to be maintained at low percentage or rate, ER should $>0$. If more $\mathrm{H}_{2}$ product is desired, $\mathrm{S} / \mathrm{B}$ should be increased, and optimum value depends on the $\mathrm{H}_{2} / \mathrm{CO}$ wanted. For chemical synthesis whereas high pure component of $\mathrm{CO}$ and $\mathrm{H}_{2}$ required, steam - oxygen gasification is important, especially in providing proper ratio of $\mathrm{H}_{2}$ toward $\mathrm{CO}$, which is required for chemical synthesis such as DME $\left(\mathrm{H}_{2} / \mathrm{CO}=1\right)$ [32], and bio- 
gasoline through Fischer-Tropsch route $\left(\mathrm{H}_{2} / \mathrm{CO}=2\right)$ [33].

\section{Conclusion}

CFB biomass gasifier model for EFB was developed using Aspen Hysys at steady state condition. The results of syngas obtained from simulation and sensitivity analysis were in good agreement with reference data, especially for $\mathrm{CO}$ and $\mathrm{H}_{2}$ as main component of syngas.

Key operating parameters simulated includes, gasifier/reactor temperature, $\mathrm{S} / \mathrm{B}$ and $\mathrm{ER}$, while other important parameters such as operating pressure, steam temperature, and $\mathrm{O}_{2}$ temperature remain constant during the simulation.

At higher temperatures, the performance of gasifier improves. It results in higher yield of syngas. To get higher yield of syngas, optimum gasifier operating temperature revealed by this study is started from 800 ${ }^{\circ} \mathrm{C}$. At $800{ }^{\circ} \mathrm{C}$, yield of $\mathrm{H}_{2}$ is at its peak.

Optimum steam to biomass ratio depends on the ratio of $\mathrm{H}_{2}$ to $\mathrm{CO}$ requirement for further chemical or fuel synthesis.S/B determine $\mathrm{H}_{2}$ composition in product syngas, $\mathrm{S} / \mathrm{B}$ directly proportional with $\mathrm{H}_{2}$ composition, the higher the $\mathrm{S} / \mathrm{B}$, the higher the $\mathrm{H} 2$ composition. Value of ER below 1 gives gasification reaction, and value of $\mathrm{ER}=0$ give highest yield of $\mathrm{CO}$ and $\mathrm{H}_{2}$ at constant $\mathrm{S} / \mathrm{B}$ value $>0$, and $\mathrm{CH}_{4}$ yield is highest as well. High $\mathrm{CH}_{4}$ is undesirable since it will lower the value of syngas efficiency.

In the future study, CFB gasifier model developedwill be used as a basis to simulate chemical production based on EFB gasification in Aspen Hysys simulator.

\section{References}

[1] E. Hutrindo, Modul Pengenalan Bioenergi, Kesatu. East Jakarta: Pusdiklat Ketenagalistrikan, Energi Baru, Terbarukan, dan Konservasi Energi, (2015).

[2] K. Abdullah, "Biomass Energy Potentials And Utilization In Indonesia,’Dept. of Agri.Eng. IPB andIRES, (2006). www.researchgate.net. [Accessed 20-May-2018].

[3] P. Basu, Biomass Gasification and Pyrolysis. Burlington, Massachusets: Elsevier, (2010).

[4] H. Hermansyah, A. P. Wisman, D. Firdaus, R. Arbianti, T. S. Utami, and A. Kurnia, "Effect of aeration and nutrients on Saccharomyces cerevisiae cultivation using lignocellulosic hydrolysate from Empty Fruit Bunch," Int. J. Technol., vol. 6, no. 7, pp. 1110-1118, (2015).

[5] T. Wang, Y. Li, L. Ma, and C. Wu, "Biomass to dimethyl ether by gasification/synthesis technology-an alternative biofuel production route," Front. Energy Power Eng. China, vol. 5, no. 3, pp. 330-339, (2011).

[6] M. Salomon, M. F. Gómez, C. Erlich, and A. Martin, "Pelletization: An alternative for polygeneration in the palm oil industry,"
Biomass Convers. Biorefinery, vol. 3, no. 3, pp. 213-229, (2013).

[7] M. A. Sukiran, N. O. R. Kartini, A. B. U. Bakar, and C. M. E. E. Chin, "Optimization of Pyrolysis of Oil Palm Empty Fruit Bunches Optimization of Pyrolysis of Oil Palm Empty Fruit Bunches," Am. J. Appl. Sci., vol. 21, no. 6, pp. 653-658, (2009).

[8] M. A. A. Mohammed, A. Salmiaton, W. A. K. G. Wan Azlina, and M. S. Mohamad Amran, "Gasification of oil palm empty fruit bunches: A characterization and kinetic study," Bioresour. Technol., vol. 110, pp. 628-636, (2012).

[9] Y. S. Pradana and A. Budiman, "Bio-syngas derived from Indonesian oil palm empty fruit bunch (EFB) using middle-scale gasification," $J$. Eng. Sci. Technol., vol. 10, no. Spec.issue8, pp. 1-8, (2015).

[10] T. Ogi, M. Nakanishi, Y. Fukuda, and K. Matsumoto, "Gasification of oil palm residues (empty fruit bunch) in an entrained-flow gasifier," Fuel, vol. 104, pp. 28-35, (2013).

[11] A. Inayat, C. Ghenai, M. Naqvi, M. Ammar, M. Ayoub, and M. N. B. Hussin, "Parametric Study for Production of Dimethyl Ether (DME) As a Fuel from Palm Wastes," Energy Proc., vol. 105, pp. 1242-1249, (2017).

[12] M. Bassyouni et al., "Date palm waste gasification in downdraft gasifier and simulation using ASPEN HYSYS," Energy Convers. Manag., vol. 88, pp. 693-699, (2014).

[13] B. Chutichai, Y. Patcharavorachot, S. Assabumrungrat, and A. Arpornwichanop, "Parametric analysis of a circulating fluidized bed biomass gasifier for hydrogen production," Energy, vol. 82, pp. 406-413, (2015).

[14] R. Nayak and R. Mewada, "Simulation of Coal Gasification Process using ASPEN PLUS",in Int. Conf. Curr. trends Technol., (2011).Ahmedabad,

Pakistan[Online].Available:http://nuicone.org/sit e/common/proceedings/Chemical/oral/CH_18.pd f. [Accessed: 10 May2018].

[15] M. S. Eikeland, R. K. Thapa, and B. M. Halvorsen, "Aspen Plus Simulation of Biomass Gasification with Known Reaction Kinetic," in Proceeding of $56^{\text {th }}$ SIMS,(2015). Linkoping, Sweden[Online].Available:http://www.ep.liu.se/ ecp/119/015/ecp15119015.pdf.[Accessed:10May 2018].

[16] K. A. Kishore and K. A. V Ramanjaneyulu, "Simulation of Biomass Gasification in Fluidized Bed Using Aspen Plus," in 6th Int. Conf. Chem. Biol. Environ. Sci., (2015). Dubai, UAE

[Online]. Available:http://psrcentre.org/images/extraimage s/915012.pdf. [Accessed: 10 May 2018].

[17] W. Doherty, A. Reynolds, and D. Kennedy, "Simulation of a Circulating Fluidised Bed 
Biomass Gasifier using ASPEN Plus: a Performance Analysis," in 21st Int. Conf. on Eff., Cost, Opt., Sim. and Env. Impact of Ener. Syst., (2008).Krakow,Poland[Online].Available:https:// arrow.dit.ie/cgi/viewcontent.cgi? article $=1009 \& \mathrm{c}$ ontext=engschmeccon. [Accessed: 11 May 2018]

[18] M. Siedlecki, W. de Jong, and A. H. M. Verkooijen, "Fluidized bed gasification as a mature and reliable technology for the production of bio-syngas and applied in the production of liquid transportation fuels-a review," Energies, vol. 4, no. 3, pp. 389-434, (2011).

[19] P. Lahijani, G. D. Najafpour, Z. Alimuddin, and M. Mohammadi, "Air Gasification of Palm Empty Fruit Bunch in a Fluidized Bed Gasifier Using Various Bed Materials," in World Renew. Energy Congr., (2011). Linkoping, Sweden [Online].Available:http://www.ep.liu.se/ecp/057/ vol12/035/ecp57vol12_035.pdf. [Accessed:11 May 2018].

[20] W. Doherty, A. Reynolds, and D. Kennedy, "The Effect of Air Preheating in a Biomass CFB Gasifier using ASPEN Plus Simulation,"Biomass Bioenergy, vol. 33, no.9, pp. 1158-1167(2009).

[21] R. Fatoni, S. Gajjar, S. Gupta, S. Handa, and A. Elkamel, "Modeling Biomass Gasification in a Fluidized Bed Reactor",in Int. Conf. Ind. Eng. Oper. Manag., (2014). Bali, Indonesia [Online].Available:http://ieomsociety.org/ieom2 014/pdfs/243.pdf. [Accessed:13 May 2018].

[22] H. Florence and A. Bour, Modelling and Optimization of a Process from Biomass to Liquid Fuels via Fischer-Tropsch Synthesis. Norway: NTNU,(2016).

[23] "HYSYS Design Tutorial For CHEE 332" Queen 'sUniversity Department of Chemical Engineering." pp. 1-36, (2013).

[24] Q. Miao, J. Zhu, S. Barghi, C. Wu, X. Yin, and Z. Zhou, "Modeling biomass gasification in circulating fluidized beds," Renew. Energy, vol. 50, pp. 655-661, (2013).

[25] B. Buragohain, P. Mahanta, and V. S. Moholkar, "First principles design of a circulating fluidized bed ( CFB ) biomass gasifier.," in New Tech for Rural Dev. Hav. Potential for Commerc. New Delhi: Allied Publisher,(2009).

[26] J. Han et al., "Modeling downdraft biomass gasification process by restricting chemical reaction equilibrium with Aspen Plus," Energy Convers. Manag., vol. 153, no. August, pp. 641648, (2017).

[27] A. Kumar, D. D. Jones, and M. A. Hanna, "Thermochemical biomass gasification: A review of the current status of the technology," Energies, vol. 2, no. 3, pp. 556-581, (2009).

[28] D. Toporov and R. Abraham, "Gasification of low-rank coal in the High-Temperature Winkler (HTW) process," J. South. African Inst. Min.
Metall., vol. 115, no. 7, pp. 589-597, (2015).

[29] "Phyllis2 - coal, lignite (\#2847)." [Online]. Available:https://www.ecn.nl/phyllis2/Biomass/ View/2847. [Accessed: 20-May-2018].

[30] N. Clausen, L. R., Elmegaard, B., \& Houbak. Design of novel DME/methanol synthesis plants based on gasification of biomass.Denmark: DTU, (2011).

[31] J. E. Preciado, J. J. Ortiz-Martinez, J. C. Gonzalez-Rivera, R. Sierra-Ramirez, and G. Gordillo, "Simulation of synthesis gas production from steam oxygen gasification of colombian coal using aspen plus," Energies, vol. 5, no. 12, pp. 4924-4940, (2012).

[32] A. M. Parvez, T. Wu, S. Li, N. Miles, and I. M. Mujtaba, "Bio-DME production based on conventional and $\mathrm{CO} 2$-enhanced gasification of biomass: A comparative study on exergy and environmental impacts," Biomass Bioenergy, vol. 110, no. September 2017, pp. 105-113, (2018).

[33] F. Trippe, et al., "Comprehensive technoeconomic assessment of DME synthesis and Fischer-Tropsch synthesis as alternative process steps within biomass-to-liquid production," Fuel Process. Technol., vol. 106, pp. 577-586, (2013). 